\title{
Kinetic characteristics of $\beta$-cyclodextrin production by cyclodextrin glycosyltransferase from newly isolated Bacillus sp. C26
}

\author{
Benjamas Cheirsilp* \\ Department of Industrial Biotechnology \\ Faculty of Agro-Industry \\ Prince of Songkla University \\ Hat-Yai, 90112, Thailand \\ E-mail: benjamas.che@psu.ac.th \\ Suleeporn Kitcha \\ Department of Industrial Biotechnology \\ Faculty of Agro-Industry \\ Prince of Songkla University \\ Hat-Yai, 90112, Thailand \\ Supasilp Maneerat \\ Department of Industrial Biotechnology \\ Faculty of Agro-Industry \\ Prince of Songkla University \\ Hat-Yai, 90112, Thailand
}

Financial support: Thai Government and Prince of Songkla University in the fiscal year of 2006-2008 under Grant AGR5011990074S.

Keywords: Bacillus subtilis ZK8, cell adsorption, jiean- peptide, response surface methodology, wood chips.

Abbreviations: CD: cyclodextrin
CGTase: cyclodextrin glycosyltransferase
DP: degree of polymerization

The kinetic characteristics of $\beta$-cyclodextrin production by a cyclodextrin glycosyltransferase (CGTase) produced by Bacillus sp. C26, a new isolate from a soil sample was investigated. Considering highest yield and initial production rate of $\beta$-cyclodextrin, among the starches examined, soluble starch, tapioca starch, sago starch, corn starch and rice starch, tapioca starch was the best substrate for this CGTase. The optimum temperature for tapioca starch gelatinization prior to its use as a substrate for $\beta$-cyclodextrin production was $65^{\circ} \mathrm{C}$. The yield and initial production rate of $\beta$ cyclodextrin increased with increasing starch concentration up to $6 \%$ and an enzyme concentration up to $48 \mathrm{U} / \mathrm{g}$-starch. The kinetic parameters of $V_{\max }$ and $K_{m}$ of $\beta$-cyclodextrin production from tapioca starch by CGTase were $1.59 \mathrm{mg} / \mathrm{mL} / \mathrm{h}$ and $22.3 \mathrm{mg} / \mathrm{mL}$, respectively. Considering high initial production rate and high yield of $\beta$-cyclodextrin, the optimum reaction temperature was at $50^{\circ} \mathrm{C}$. This study provided the necessary kinetic information that may be useful to define the most suitable condition for industrialized production of $\beta$-cyclodextrin with the high yield and productivity.

Cyclomaltodextrins, more commonly known as
*Corresponding author

cyclodextrins (CDs) are cyclic oligosaccharides. CDs are enzymatically modified starches produced by the action of cyclodextrin glycosyltransferase (CGTase) (EC 2.4.1.19) on starch or a starch derivative. The $\alpha-1,4$ linkage of the starch is retained to form a closed circular molecule, usually containing six, seven, or eight glucose molecules. These are referred to $\alpha-, \beta-$, and $\gamma$ - forms of $C D$, respectively. These CDs are capable of association with a wide variety of molecules to form inclusion complexes. These complexes have altered chemical and physical properties that can introduce modified and often desirable properties, especially to the guest molecules, such as altered solubility, volatility and chemical stability. These benefits have been of use in a wide variety of areas such as the food, chemical, pharmaceutical, analytical, diagnostic, cosmetic, agriculture, and plastic industries and as stabilizing agents, emulsifiers, antioxidants and in other industrial areas (Cao et al. 2005).

The main advantage of enzymatic production is sterio-, regio- and chemoselectivity and specificity. Biotechnology processes may have potential in CDs production, specifically in special form of CD. This will depend on the screening of novel CGTases from novel species which are able to produce specific form of $\mathrm{CD}$ in high yield at high 

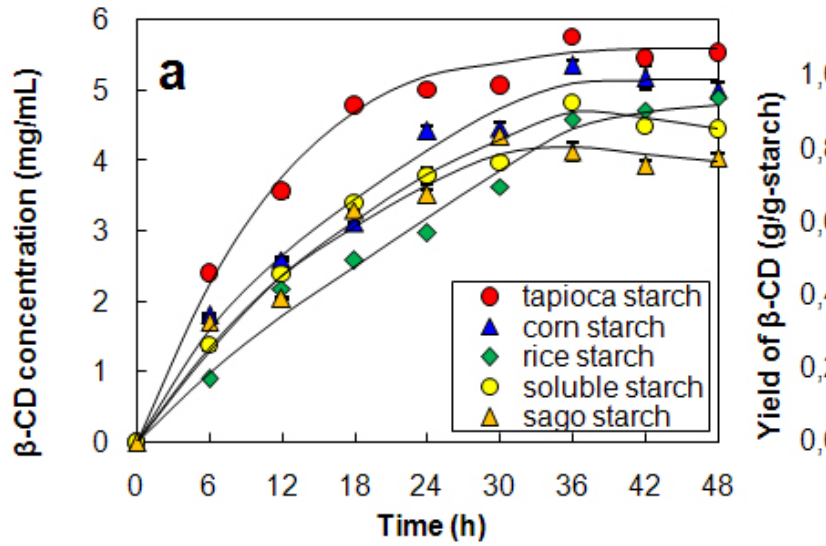

Figure 1. Effect of starch source on $\beta$-CD production by CGTase.

a) time course.

b) yield and initial rate.

Different letters indicate significant differences $(p<0.05)$.

productivity. Moreover, the study on kinetic characteristics of novel CGTases will lead to the most suitable condition to improve the yield and productivity. Different CGTase enzymes produce a mixture of $\alpha-, \beta-$, and $\gamma$-CDs in different ratios. However, most CGTases produce $\beta-C D$ as the main product. CGTase producing primarily $\alpha-$ and $\gamma-\mathrm{CD}$ are relatively rare (Gawande and Patkar, 2001). The $\beta$-form of $\mathrm{CD}$ is reported to be more suitable for industrial use, since inclusion complexes can be prepared easily and are very stable due to the low solubility of the $\beta$-CD in water. In addition, the yield of $\beta$-CD from starch is usually higher than that of the other CDs (Mahat et al. 2004). The $\beta-C D$ produced by CGTase depends on reaction conditions, substrate concentration, amount of enzyme and source of CGTase (Rha et al. 2005). To determine the optimal condition for $\beta$-CD production by CGTase, it is essential to understand the kinetics of the reaction. Until now there have been several reports on factors affecting $\mathrm{CD}$ production by CGTases from various microorganisms (Kim et al. 1995; Charoenlap et al. 2004; Szerman et al. 2007). Some reports studied on the kinetics of CGTase but most of them focused only on the effect of substrate concentration (Gawande and Patkar, 2001; Matioli et al. 2002; Arya and Srivastava, 2006; Moriwaki et al. 2007).

In this study, CGTase produced by a newly isolated Bacillus sp. C26 (Kitcha et al. 2008) was used to produce $\beta$-CD from starch. The $\beta$-CD production by different sources of CGTase would lead to change in the kinetic behavior with impact on yield and productivity. Thus, the kinetic characteristic of this novel CGTase is among the main necessary information for developing the production process with high productivity and yield. The effects of starch source, temperature for starch gelatinization, substrate concentration, enzyme concentration and reaction temperature on the kinetics of $\beta-\mathrm{CD}$ production by CGTase were investigated.

\section{MATERIALS AND METHODS}

\section{Materials}

Cyclodextrin glycosyltransferase was produced by a newly isolated C26 strain from soil collected from corn plantation in Prince of Songkla University, Thailand in 2007 and identified as Bacillus sp. by alignment of a partial $16 \mathrm{~S}$ rDNA sequence (Kitcha et al. 2008). Its optimum reaction $\mathrm{pH}$ and temperature are 8.5 and $50^{\circ} \mathrm{C}$, respectively. All chemicals used were of reagent grade.

\section{Preparation of CGTase}

A loopful of fresh bacterial culture was inoculated into 5 $\mathrm{mL}$ Horikoshi II broth (Mahat et al. 2004) and incubated at $37^{\circ} \mathrm{C}$, with shaking at $200 \mathrm{rpm}$ for $24 \mathrm{hrs}$. Five percent of the cell suspension with an optical density of about $1.0(660$ $\mathrm{nm}$ ) was then inoculated into a $250 \mathrm{~mL}$ conical flask

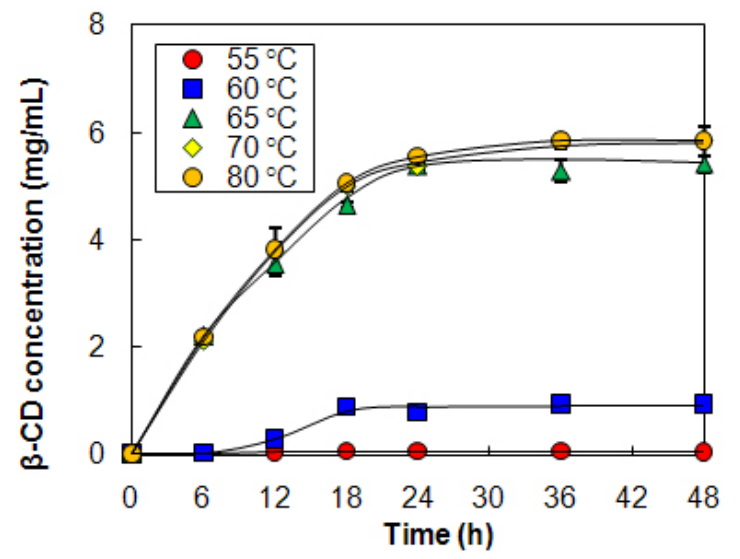

Figure 2. Effect of the gelatinization temperature for tapioca starch on $\beta-C D$ production by CGTase. 

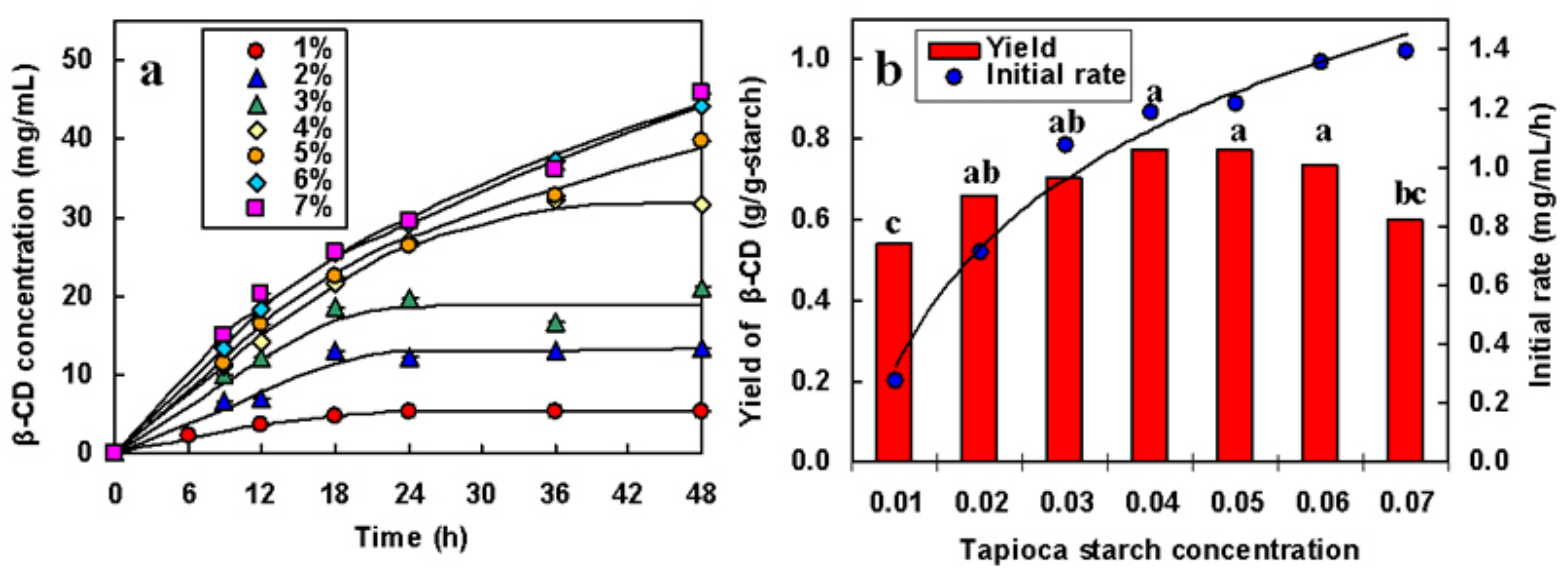

Figure 3. Effect of tapioca starch concentration on $\beta$-CD production by CGTase.

a) time course.

b) yield and initial rate.

Different letters indicate significant differences $(p<0.05)$.

containing $50 \mathrm{~mL}$ of medium and again incubated at $37^{\circ} \mathrm{C}$ and $200 \mathrm{rpm}$. After $48 \mathrm{hrs}$ growth the bacteria were sedimented from the culture broth at $8,000 \mathrm{rpm}$ for $15 \mathrm{~min}$ and solid ammonium sulfate was added to the supernatant at $4^{\circ} \mathrm{C}$, to achieve $70 \%$ saturation and the precipitate obtained was collected by centrifugation. This precipitate was dissolved in $20 \mathrm{mM}$ phosphate buffer $\left(\mathrm{pH} 8.0\right.$ at $\left.4^{\circ} \mathrm{C}\right)$ and the solution was dialyzed using a membrane with an $8,000 \mathrm{Da}$ molecular cut-off at $4^{\circ} \mathrm{C}$ in the same buffer. Considering the downstream cost and sufficient purity, the partially purified enzyme thus obtained was employed for further studies.

\section{$\beta$-cyclodextrin production}

$1 \%$ suspensions of soluble starch, tapioca starch, sago starch, corn starch and rice starch in $0.1 \mathrm{M}$ Glycine- $\mathrm{NaOH}$ buffer $\mathrm{pH} 8.5$ were gelatinized at $70^{\circ} \mathrm{C}$ for $1 \mathrm{hr}$. One gram of solubilized starch was reacted with $12 \mathrm{U}$ of CGTase at $50^{\circ} \mathrm{C}$. The effect of temperature for gelatinization was investigated by varying the temperature in the range of 55$80^{\circ} \mathrm{C}$. The effect of substrate and enzyme concentrations was examined in the range of 1-7\% and 12-192 U/g-starch, respectively.

\section{Determination of kinetic parameters}

Initial production rates, expressed as $\mathrm{mg} / \mathrm{mL} \quad \beta-\mathrm{CD}$ produced per hour, were determined from the time course of $\beta$-CD concentration by estimating the slope of the $\beta$-CD production curve at the beginning of the reaction. From the data on initial production rates as a function of substrate concentrations up to 7\%, the kinetic parameters $V_{\max }$ and $K_{m}$ in Michaelis-Menten model were determined by fitting the data of the initial production rates and substrate concentrations to the Lineweaver-Burk plot:
$\frac{1}{v}=\frac{1}{V_{\max }}+\frac{K_{\min }}{V_{\max }}\left(\frac{1}{S}\right)$

where $v$ is the initial production rate $(\mathrm{mg} / \mathrm{mL} / \mathrm{h}), V_{\max }$ is the maximum velocity, $K_{m}$ is the Michaelis-Menten constant $(\mathrm{mg} / \mathrm{mL})$ and $s$ is the substrate concentration $(\mathrm{mg} / \mathrm{mL})$.

\section{Analysis}

CGTase activity was assayed by the method based on the reduction in the colour intensity of phenolphthalein after complexing with $\beta$-CD (Arya and Srivastava, 2006). The reaction mixture containing $0.5 \mathrm{~mL}$ of $4 \%$ soluble starch in $0.1 \mathrm{M}$ phosphate buffer $\mathrm{pH} 8.0$ and $0.5 \mathrm{~mL}$ of CGTase solution was incubated at $60^{\circ} \mathrm{C}$ for $10 \mathrm{~min}$. The reaction was stopped by boiling for $5 \mathrm{~min}$. Then $0.5 \mathrm{~mL}$ of $0.02 \%$ phenolphthalein in $0.005 \mathrm{M} \mathrm{Na}_{2} \mathrm{CO}_{3}$ was added. The reduction in the colour intensity was measured at $550 \mathrm{~nm}$. One unit of CGTase was defined as the amount of enzyme that formed $1 \mu \mathrm{mol}$ of $\beta-\mathrm{CD} \mathrm{min}^{-1}$ under standard conditions. A standard graph was plotted with $\beta-\mathrm{CD}$.

All experiments were performed at least in duplicate. Analysis of variance was performed to calculate significant differences in treatment means and the least significant difference $(p<0.05)$ was used to separate means, using the SPSS software version 11.

\section{RESULTS AND DISCUSSION}

Depending on the source organism, CGTases often display varying levels of $\beta$-CD production on various kinds of starches. Time courses of $\beta$-CD production from different starch sources by Bacillus sp. C26 CGTase are shown in Figure 1a. The yield and initial rate of $\beta-C D$ production using various starch sources were also compared as shown 


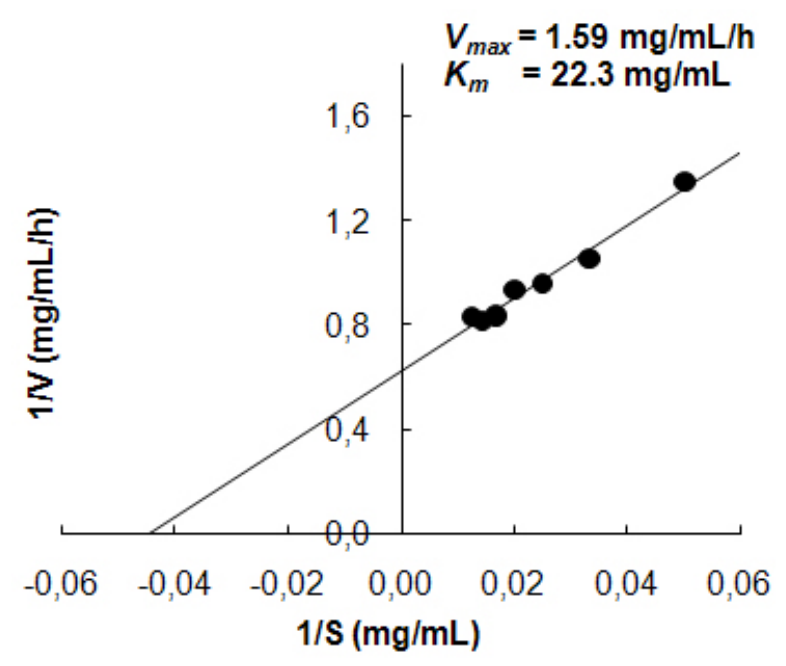

Figure 4. Lineweaver-Burk plot for determining the $V_{\max }$ and $K_{m}$ of the CGTase reaction on tapioca starch.

in Figure 2. CGTase produced $\beta-C D$ from tapioca starch rapidly and achieved a maximum concentration within 24 hrs. While the $\beta$-CD from corn and soluble starch was produced slower and increased up to the maximum level at 36 hrs. The $\beta-C D$ from rice starch was produced slowest but the final $\beta-C D$ concentration was higher than that of soluble and sago starch. The $\beta-C D$ production from sago starch ceased at $30 \mathrm{hrs}$ resulting in the lowest final $\beta-\mathrm{CD}$ concentration. The highest $\beta-\mathrm{CD}$ production from tapioca starch was also observed in $\mathrm{CD}$ production by CGTase from Bacillus sp. G1 (Sian et al. 2005), while soluble starch was the best substrate for CGTase from Klebsiella pneumoniae AS-22 (Gawande and Patkar, 2001). This might be due to the differences in the starch granule structure and properties of CGTase from different microorganisms.

In Figure 2, the yield of $\beta-C D$ from tapioca starch was higher than the others. However, the difference in $\beta-C D$ yields from various starches was very small. Among the starches examined, sago starch gave the lowest $\beta-C D$ yield. It was reported that CGTases are active on both starch fractions: amylose and amylopectin but the high amylopectin content were preferred for CGTase activity (Gawande and Patkar, 2001; Grüll and Stifter, 2001). Pishtiyski and Zhekova (2006) reported that the CD yield from amylose was considerably lower that from amylopectin. This might be due to the level of branched structure of amylopectin which allows the enzyme reaction to start from a great number of points (nonreducing ends of side-chains). However, the literature data for the preference of CGTase for amylose and amylopectin are contradictory. According to Egorov et al. (1988) the preferred substrate is amylose because of the lack of side-chains. In this study, from the literature data although the amylose content of corn starch $(23.4 \%)$ was higher than that of tapioca starch (17.9\%) and rice starch (13.2\%) (Srichuwong et al. 2005), the $\beta$-CD yield from corn starch was lower than that of tapioca starch and not significantly different to that of rice starch (Figure 2). In addition, although rice starch has higher amylopectin content $(86.8 \%)$ compared to tapioca starch $(82.1 \%)$, it did not gave higher yield of $\beta$-CD. Therefore, it was not possible to describe the difference in the yield of $\beta-C D$ by the content of amylose/amylopectin. Besides amylose/amylopectin content, it was reported that CGTase preferred native starch which high molecular mass and low dextrose equivalent (Pishtiyski and Zhekova, 2006). According to the literature data, the CGTase can directly cyclize oligosaccharides consisting of at least eight glucose units. The shorter oligosaccharide chain has to be first lengthened by disproportion action of the enzyme and then cyclized (Martins and Hatti-Kaul, 2003). The longer the chain, the higher the amount of cyclodextrin formed (Brunet et al. 1998). Comparing the degree of polymerization (DP) of starches, it was found that tapioca starch contained higher proportion of chains with DP 9-12 $(36.3 \%)$ than that of rice, corn and sago starch $(34.5 \%$, $31.4 \%$ and $28.1 \%$, respectively) (Srichuwong et al. 2005). It is likely that the $\beta-C D$ yield was positively correlated with the proportions of unit-chains with DP 9-12. More considerable was the initial rate of $\beta-C D$ production from rice starch was found to be lowest compared to that of the others (Figure 1b). One of the main factors for the digestibility of starch granules by enzyme has been considered to be either viscosity or granule size (Pishtiyski and Zhekova, 2006). The higher initial rate of $\beta-C D$ production from tapioca starch than the others could be explained by its lower viscosity and higher solubility (Mishra and Rai, 2006). However, the lowest initial rate of $\beta-C D$ production from rice starch could not be explained by the granule size because the granule size of rice starch was smallest compared to the others (Srichuwong et al. 2005). Another explanation of lowest initial production rate of $\beta$ CD from rice starch may be found in the highest amylopectin content. Though Bacillus sp. C26 CGTase can act on various starch sources, the yield and initial rate of $\beta$ CD production from tapioca starch were highest compared to the others. This is an advantage for this enzyme because tapioca starch is comparatively low cost and easily available in Thailand.

It has been reported that the temperature for gelatinization affected the yield of $\beta$-CD production by CGTase (Kim et al. 1995). In that report, a temperature below the gelatinization temperature of starch benefited the removal of residual starch but it gave lower content of CD compared to the gelatinization temperature. According to the literature data, the gelatinization temperature for tapioca starch is 60$66^{\circ} \mathrm{C}$ (Srichuwong et al. 2005). Tapioca starch was heated at temperatures in the range of $55-80^{\circ} \mathrm{C}$ for $1 \mathrm{hr}$ and then was used for $\beta-C D$ production. The amount of $\beta-C D$ from heat-treated starch at $60^{\circ} \mathrm{C}$ was much lower than that at 65 , 
70 and $80^{\circ} \mathrm{C}$. From heat-treated starch above $65^{\circ} \mathrm{C}$, the $\beta$ $\mathrm{CD}$ were produced fully and equally. The observation is supported by the fact that the temperature above $65^{\circ} \mathrm{C}$ is the range of gelatinization temperature for tapioca starch, namely all hydrogen bonds continue to disrupt followed by the attachment of water molecules and resulting in the continuous swelling of the granule. The swelled granule of starch could facilitate the digestibility of the enzyme. From this result it could be inferred that starch was partially transformed into a reactive structure at $60^{\circ} \mathrm{C}$ and totally transformed at the temperature above gelatinization temperature of $65-80^{\circ} \mathrm{C}$. The similar result was also observed in the $\mathrm{CD}$ production from corn starch by a CGTase from Bacillus macerans (Kim et al. 1995). They reported that corn starch heat-treated at $65^{\circ} \mathrm{C}$, lower temperature than its gelatinization temperature $72^{\circ} \mathrm{C}$, gave a $20 \%$ lower amount of $\mathrm{CD}$ production compared to that at $70^{\circ} \mathrm{C}$. From our results we have defined the optimum temperature for gelatinization of tapioca starch for $\beta-C D$ production from Bacillus sp. $\mathrm{C} 26$ at $65^{\circ} \mathrm{C}$. According to Szerman et al. (2007), the minimum temperature required to obtain a reactive structure of cassava starch for $\beta-C D$ production from CGTase of Bacillus circulans DF 9R was $70^{\circ} \mathrm{C}$ which was higher than the gelatinization temperature at $65^{\circ} \mathrm{C}$. Compared to CGTase in their study, CGTase in this study is considered to be more useful to convert starch to $\beta-C D$ with lower energy requirement.

As tapioca starch is an inexpensive raw material in Thailand, the production of $\beta-\mathrm{CD}$ at a high concentration of starch is desirable from an economic standpoint. The effect of tapioca starch concentration on the $\beta$-CD production was investigated with the amount of CGTase fixed at $12 \mathrm{U} / \mathrm{g}$ starch (Figure 3). The total amount of $\beta-\mathrm{CD}$ produced increased with an increasing concentration of tapioca starch. The highest amounts of $\beta-\mathrm{CD}$ obtained at $6 \%$ and $7 \%$ tapioca starch were not significantly different. The effect of tapioca concentration on the kinetics of $\beta-C D$ production is shown in Figure 3b. Even though the initial rate of $\beta$-CD production increased until a starch concentration of $7 \%$, the increased initial rate at $7 \%$ compared to that at $6 \%$ was small. The yield of $\beta-C D$ also increased with increasing starch concentration but became constant at a tapioca starch concentration of between $4 \%$ to $6 \%(p<0.05)$. At $7 \%$ starch concentration, the yield of $\beta$ $\mathrm{CD}$ decreased. This might be due to the higher viscosity of the starch concentration at $7 \%$ reduced the ability of the enzyme. Taking into account the highest yield and high initial rate of $\beta-\mathrm{CD}$ production, a concentration of tapioca starch of $6 \%$ was chosen as being optimum for further studies. From this result, this CGTase from Bacillus sp. C26 is more suitable for $\mathrm{CD}$ production from tapioca starch than the CGTases from Bacillus sp. G1 (Sian et al. 2005) and B. circulans DF 9R (Szerman et al. 2007) because the Bacillus sp. C26 CGTase produced highest amounts of $\beta$ $\mathrm{CD}$ at higher concentration of starch $(6 \%$ starch concentration) compared to the CGTases from those bacillus (5\% starch concentration).

Figure 4 shows the Lineweaver-Burk plot for the CGTase reaction on tapioca starch. The $V_{\max }$ and $K_{m}$ of CGTase were $1.59 \mathrm{mg} / \mathrm{mL} / \mathrm{h}$ and $22.3 \mathrm{mg} / \mathrm{mL}$, respectively. The $K_{m}$ parameter is correlated to the affinity of the enzyme for its substrate and it depends on the sources of the enzyme and substrate. There have been several reported $K_{m}$ values from various CGTases when soluble starch was used as the substrate, such as CGTase from Bacillus sp. G1, 0.15 $\mathrm{mg} / \mathrm{mL}$ (Sian et al. 2005); B. firmus, $1.21 \mathrm{mg} / \mathrm{mL}$ (Gawande et al. 1999); K. pneumoniae AS-22, $1.35 \mathrm{mg} / \mathrm{mL}$ (Gawande and Patkar, 2001). Comparing the same source of starch, the $K_{m}$ value of CGTase in this study for tapioca starch $(22.3 \mathrm{mg} / \mathrm{mL})$ was lower than that of CGTase from other Bacillus sp. (33.9 mg/mL) (Wang et al. 1995).

In order to determine the optimum amount of enzyme, the production of $\beta-C D$ from $6 \%$ concentration of tapioca starch with different amounts of enzyme was investigated (Figure 5). The $\beta$-CD production increased with increasing
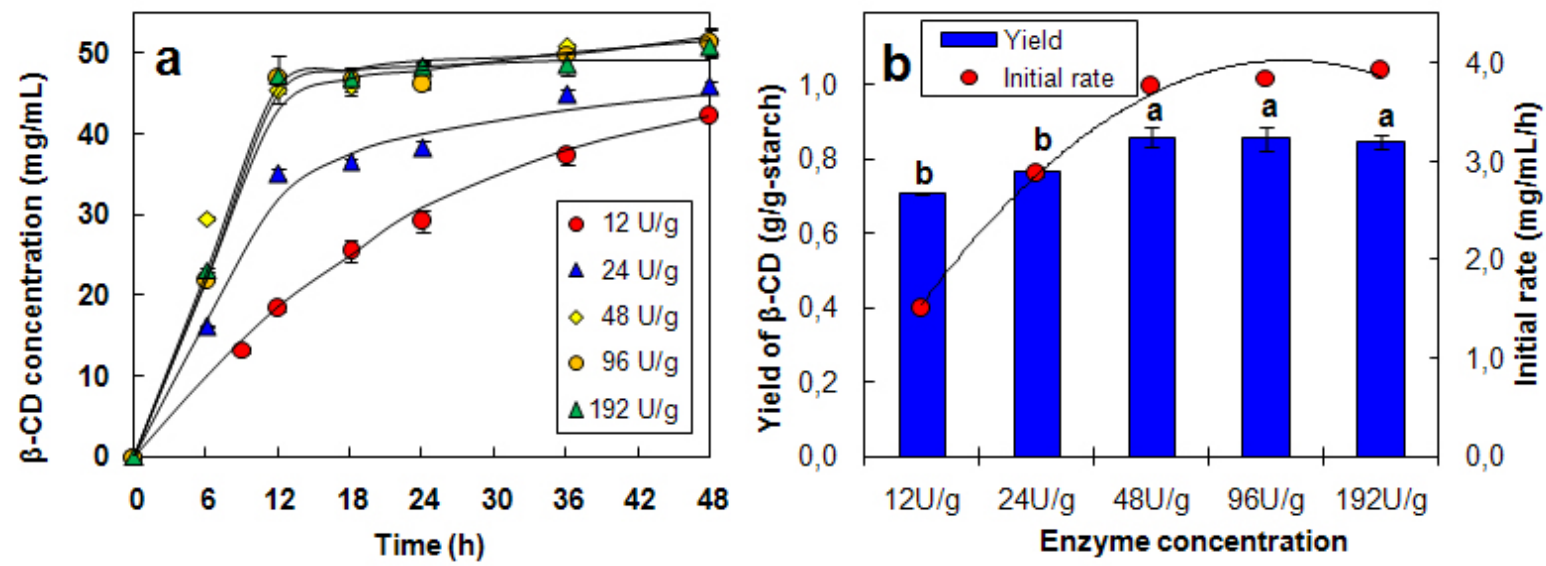

Figure 5. Effect of enzyme concentration on $\beta$-CD production by CGTase.

a) time course.

b) yield and initial rate.

Different letters indicate significant differences $(p<0.05)$. 

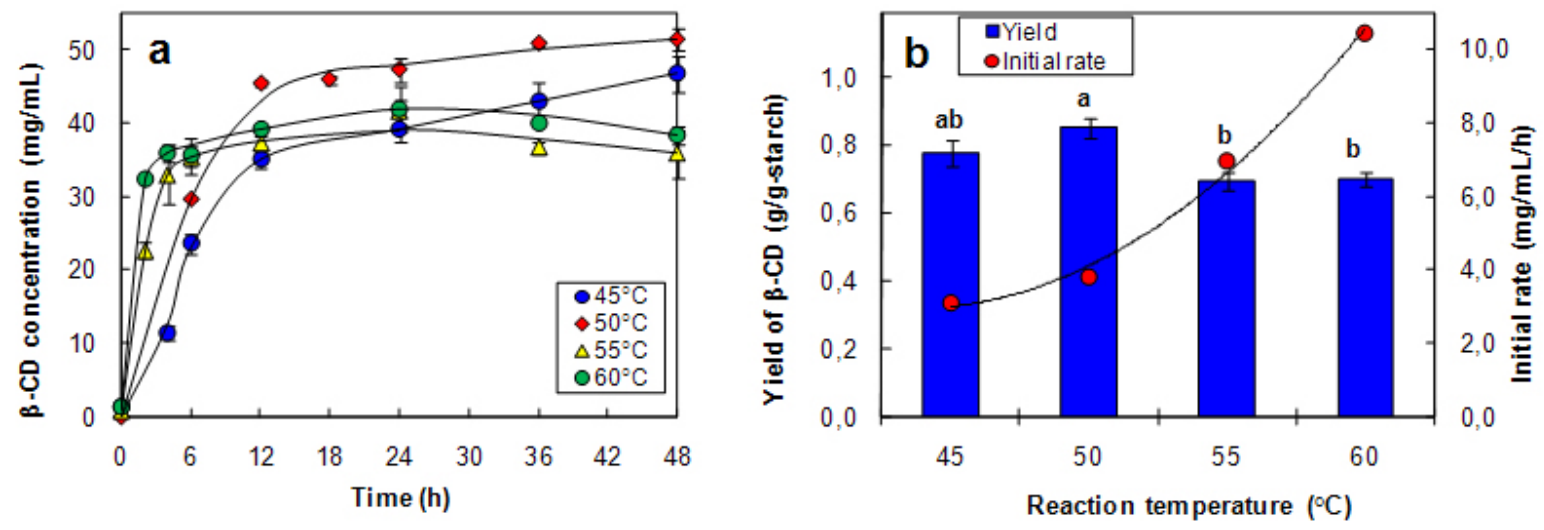

Figure 6. Effect of reaction temperature on $\beta$-CD production by CGTase.

a) time course.

b) yield and initial rate.

Different letters indicate significant differences $(p<0.05)$.

amounts of enzyme (Figure 5a). The optimum amount of enzyme to starch was found to be $48 \mathrm{U} / \mathrm{g}$-tapioca starch since above this ratio there was no further increase in $\beta-C D$ production. This result was similar to that for $\beta-\mathrm{CD}$ production by a CGTase from Bacillus circulans TISTR 907 at $50 \mathrm{U} / \mathrm{g}$-starch when sago starch was used as substrate (Charoenlap et al. 2004) and for $\beta$-CD production by a CGTase from Bacillus macerans at $48 \mathrm{U} / \mathrm{g}$-starch when corn starch was used as substrate (Kim et al. 1995). In contrast, with increasing enzyme concentration for the $\beta$ $\mathrm{CD}$ production by CGTase from Bacillus agaradhaerens LS-3C the $\beta$-CD production decreased drastically and became undetectable at $30 \mathrm{U} / \mathrm{g}$ starch (Martins and HattiKaul, 2002). In that case it was concluded that because the CGTase from B. agaradhaerens LS-3C exhibited a low rate of $\mathrm{CD}$ production and the competing hydrolysis reactions of $\mathrm{CD}$ seemed to dominate at high concentrations of the enzyme. In this study, the yield and initial rate of $\beta-C D$ production by CGTase from Bacillus sp. C26 increased with increasing enzyme concentration and became constant at enzyme concentrations above $48 \mathrm{U} / \mathrm{g}$-starch (Figure $5 \mathrm{~b}$ ). Therefore, the enzyme concentration at $48 \mathrm{U} / \mathrm{g}$-starch was considered to be optimum for $\beta$-CD production by CGTase from Bacillus sp. C26.

The effect of reaction temperature on $\beta$-CD production was investigated by varying the reaction temperature from $45^{\circ} \mathrm{C}$ to $60^{\circ} \mathrm{C}$ (Figure 6). At higher temperature, the initial production rate of $\beta-\mathrm{CD}$ increased due to the higher kinetic energy. However, the enzyme characterized as protein, when temperature increases the protein becomes denature and loose its function in a short period of time resulting in lower yield of the product. The optimal reaction temperature for $\beta$-CD production by CGTase in this study was at $50^{\circ} \mathrm{C}$ since the maximum yield of $\beta-\mathrm{CD}$ was obtained with the higher initial production rate than that at $45^{\circ} \mathrm{C}$. The temperature above $50^{\circ} \mathrm{C}$ gave much higher initial production rate of $\beta-C D$, but this was only during the initial time (0-6 hrs). The production of $\beta-\mathrm{CD}$ at $55^{\circ} \mathrm{C}$ and $60^{\circ} \mathrm{C}$ almost ceased after $6 \mathrm{hrs}$, and the yield was then lower than that at $45^{\circ} \mathrm{C}$ and $50^{\circ} \mathrm{C}$. This could be explained by the lower thermal stability of CGTase at higher temperature. In the previous report (Kitcha et al. 2008), CGTase from Bacillus sp. $\mathrm{C} 26$ showed a maximum activity at $65^{\circ} \mathrm{C}$ and wide thermal stability at temperature from 30 to $50^{\circ} \mathrm{C}$ but it rapidly lost the activity above $55^{\circ} \mathrm{C}$. Most researches focused on the effect of temperature on the activity of the CGTase. There are only several reports on the effect of reaction temperature on the $\beta$-CD formation. In the study of Martins and Hatti-Kaul (2002) and Martins and Hatti-Kaul (2003), the $\beta-C D$ formation by the CGTase from $B$. agaradhaerens LS-3C was also found highest at $50^{\circ} \mathrm{C}$. Although the maximum activity of CGTase was found at $55^{\circ} \mathrm{C}$, the $\beta$-CD formation drastically decreased at $55^{\circ} \mathrm{C}$ and $60^{\circ} \mathrm{C}$. Szerman et al. (2007) found that the CGTase from $B$. circulans DF 9R showed the maximum $\beta$-CD production at $56^{\circ} \mathrm{C}$ but only $6 \mathrm{mg} / \mathrm{mL}$ of $\beta-\mathrm{CD}$ was obtained. This could be because the lower starch and enzyme concentrations were used.

\section{CONCLUDING REMARKS}

This study has shown the necessary information for developing the industrialized production of $\beta-C D$ by CGTase from a newly isolated Bacillus sp. C26. These included 1) the most suitable starch source which gave the highest yield and initial rate of $\beta-C D$ production for this CGTase was tapioca starch; 2) the highest production of $\beta$ $\mathrm{CD}$ with minimum requirement of starch and enzyme concentration was extracted; 3) the kinetic parameters of this CGTase using tapioca starch as a substrate was determined; and 4) the optimum reaction temperature when considering high initial production rate and yield was obtained.

\section{ACKNOWLEDGMENTS}

The authors thank Dr. Brian Hodgson for proof-reading the manuscript. 


\section{REFERENCES}

ARYA, S.K. and SRIVASTAVA, S.K. Kinetics of immobilized cyclodextrin gluconotransferase produced by Bacillus macerans ATCC 8244. Enzyme and Microbial Technology, July 2006, vol. 39, no. 3, p. 507-510.

BRUNET, Christine; LAMARE, Sylvain and LEGOY, Marie-Dominique. Studies of specific cyclodextrin production starting from pure maltooligosacharides using Thermoanaerobacter sp. cyclodextrin glycosyltransferase. Biocatalysis and Biotransformation, November 1998, vol. 16, no. 4, p. 317-327.

CAO, Xinzhi; JIN, Zhengyu; WANG, Xi and CHEN, Feng. A novel cyclodextrin glycosyltransferase from an alkalophilic Bacillus species: purification and characterization. Food Research International, April 2005, vol. 38, no. 3, p. 309-314.

CHAROENLAP, Nisanart; DHARMSTHITI, Saovanee; SISISANSANEEYAKUL, Sarote and LERTSIRI, Sittiwat. Optimization of cyclodextrin production from sago starch. Bioresource Technology, March 2004, vol. 92, no. 1, p. 4954.

EGOROV, N.; KESTNER, A. and VOKK, R. History of cyclodextrin research, properties and application. Mikrobiologia, 1988, vol. 20, p. 4-52.

GAWANDE, B.N.; Goel, A.; PATKAR, A.Y. and NENE, S.N. Purification and properties of a novel raw starch degrading cyclomaltodextrin glucanotransferase from Bacillus firmus. Applied Microbiology and Biotechnology, April 1999, vol. 51, no. 4, p. 504-509.

GAWANDE, B.N. and PATKAR, A.Y. Purification and properties of a novel raw starch degrading-cyclodextrin glycosyltransferase from Klebsiella pneumoniae AS- 22. Enzyme and Microbial Technology, June 2001, vol. 28, no. 9-10, p. 735-743.

GRÜLL, D. and STIFTER, U. Process for the production of cyclodextrins. US Patent 6235 505, 2001.

KIM, Tae-Jong; KIM, Bong-Chan and LEE, Hyun-Soo. Production of cyclodextrin using moderately heat-treated corn starch. Enzyme and Microbial Technology, 1995, vol. 17 , no. 12 , p. 1057-1061.

KITCHA, S.; MANEERAT, S. and CHEIRSILP, B. Cyclodextrin glycosyltransferase from a newly isolated alkalophilic Bacillus sp. C26. Songklanakarin Journal of Science and Technology, 2008, vol. 30, no. 6, p. 723-728.

MAHAT, Mohd Khairizal; ILLIAS, Rosli Md.; RAHMAN, Roshanida A.; RASHID, Noor Aini Abd; MAHMOOD, Nik Azmi Nik; HASSAN, Osman; AZIZ, Suraini Abdul and KAMARUDDIN, Kamarulzaman. Production of cyclodextrin glucanotransferase (CGTase) from alkalophilic Bacillus sp. TS1-1: media optimization using experimental design. Enzyme and Microbial Technology, October 2004, vol. 35, no. 5, p. 467-473.

MARTINS, Rita F. and HATTI-KAUL, Rajni. A new cyclodextrin glycosyltransferase from an alkaliphilic Bacillus agaradhaerens isolate: purification and characterization. Enzyme and Microbial Technology, January 2002, vol. 30, no. 1, p. 116-124.

MARTINS, Rita F. and HATTI-KAUL, Rajni. Bacillus agaradhaerens LS-3C cyclodextrin glycosyltransferase: activity and stability features. Enzyme and Microbial Technology, November 2003, vol. 33, no. 6, p. 819-827.

MATIOLI, Graciette; ZANIN, Gisella M. and MORAES, Flávio F. Influence of substrate and product concentrations on the production of cyclodextrins by CGTase of Bacillus firmus, strain no. 37. Applied Biochemistry and Biotechnology, March 2002, vol. 98-100, no. 1-9, p. 947960.

MISHRA, S. and RAI, T. Morphology and functional properties of corn, potato and tapioca starches. Food Hydrocolloids, July 2006, vol. 20, no. 5, p. 557-566.

MORIWAKI, Cristiane; COSTA, Glauciane L.; PAZZETTO, Rubia; ZANIN, Gisella M.; MORAES, Flávio F.; PORTILHO, Márcia and MATIOLI, Graciette. Production and characterization of a new cyclodextrin glycosyltransferase from Bacillus firmus isolated from Brazilian soil. Process Biochemistry, October 2007, vol. 42, no. 10 , p. $1384-1390$.

PISHTIYSKI, Ivan and ZHEKOVA, Boriana. Effect of different substrates and their preliminary treatment on cyclodextrin production. World Journal of Microbiology and Biotechnology, February 2006, vol. 22, no. 2, p. 109114.

RHA, Chan-Su; LEE, Dae-Hee; KIM, Sung-Gun; MIN, Won-Ki; BYUN, Seong-Goo; KWEON, Dae-Hyuk; HAN, Nam Soo and SEO, Jin-Ho. Production of cyclodextrin by poly-lysine fused Bacillus macerans cyclodextrin glycosyltransferase immobilized on cation exchanger. Journal of Molecular Catalysis B: Enzymatic, July 2005, vol. 34, no. 1-6, p. 39-43.

SIAN, Ho K.; SAID, Mamot; HASSAN, Osman; KAMARUDDIN, Kamarulzaman; ISMAIL, A. Fauzi; RAHMAN, Roshanida A.; MAHMOOD, Nik A.N. and ILLIAS, Rosli M. Purification and characterization of cyclodextrin glucanotransferase from alkalophilic Bacillus sp. G1. Process Biochemistry, March 2005, vol. 40, no. 3-4, p. 1101-1111.

SRICHUWONG, Sathaporn; SUNARTI, Titi Candra; MISHIMA, Takashi; ISONO, Naoto and HISAMATSU, 
Cheirsilp, B. et al.

MAKOTO. Starches from different botanical sources I: Contribution of amylopectin fine structure to thermal properties and enzyme digestibility. Carbohydrate Polymer, June 2005, vol. 60, no. 4, p. 529-538.

SZERMAN, Natalia; SCHROH, Ignacio; ROSSI, Ana Lía; ROSSO, Adriana M.; KRYMKIEWICZ, Norberto and FERRAROTTI, Susana A. Cyclodextrin production by cyclodextrin glycosyltransferase from Bacillus circulans DF 9R. Bioresource Technology, November 2007, vol. 98, no. 15 , p. $2886-2891$.

WANG, G.S.; CHEN, P.L.; LIU, Y.T. and WANG, L.H. Purification of cyclodextrin glycosyltransferase from a mutant of Bacillus species. Report of the Taiwan Sugar Research Institute, 1995, vol. 150, p. 53-66. 